\title{
Kähler Dark Matter, Dark Energy Cosmic Density and Their Coupling
}

\section{Mohamed S. El Naschie}

Department of Physics, Faculty of Science, Alexandria University, Alexandria, Egypt

Email: Chaossf@aol.com

How to cite this paper: El Naschie, M.S. (2016) Kähler Dark Matter, Dark Energy Cosmic Density and Their Coupling. Journal of Modern Physics, 7, 1953-1962. http://dx.doi.org/10.4236/jmp.2016.714173

Received: October 19, 2016

Accepted: October 28, 2016

Published: October 31, 2016

Copyright (๑) 2016 by author and Scientific Research Publishing Inc. This work is licensed under the Creative Commons Attribution International License (CC BY 4.0).

http://creativecommons.org/licenses/by/4.0/

\begin{abstract}
We utilize homology and co-homology of a K3-Kähler manifold as a model for spacetime to derive the cosmic energy density of our universe and subdivide it into its three fundamental constituents, namely: 1) ordinary energy; 2) pure dark energy and 3) dark matter. In addition, the fundamental coupling of dark matter to pure dark energy is analyzed in detail for the first time. Finally, the so-obtained results are shown to be in astounding agreement with all previous theoretical analysis as well as with actual accurate cosmic measurements.
\end{abstract}

\section{Keywords}

Kähler Topology, Dark Matter, E-Infinity, Super Strings, Golden Mean Computer, Kerr Black Hole Geometry, Accelerated Cosmic Expansion, Fractal Cantorian Spacetime

\section{Introduction and Background Information}

In many previous publications [1]-[80], we considered the major problems of dark energy as well as the related quest to elucidate the missing mass of the universe which was dubbed "Dark Matter" [6] [38] [39]. In short it was found that a highly accurate estimate of these densities may be found by equating the Lorentzian Gamma factor $\gamma$ of Einstein's equation of maximal energy $\left(\mathrm{E}=\mathrm{mc}^{2}\right.$ as given for $\gamma=1$ where $\mathrm{m}$ is the mass and $c$ is the velocity of light) to the ratio of the Betti number $b_{2}$ of Einstein's $4 \mathrm{D}$ smooth manifold $\left(b_{2}=1\right)$ and that of a K3-Kähler manifold $b_{2}=22$ [81]-[108]. Thus inserting in $\mathrm{E}$ leads to an ordinary energy density [2] [44]

$$
\begin{aligned}
\mathrm{E}(\mathrm{O}) & =\frac{\mathrm{b}_{2}(\text { Einstein })}{\mathrm{b}_{2}(\mathrm{k} 3-\text { Kähler })} \mathrm{mc}^{2} \\
& =\frac{1}{22}\left(\mathrm{mc}^{2}\right)
\end{aligned}
$$


This is almost $4.5 \%$ of Einstein's classical energy density $\mathrm{E}=\mathrm{mc}^{2}$ from which one is naturally led to conclude that the "hidden" or missing energy density of the universe must be equal to $1-(1 / 22)=21 / 22$ i.e. $95.5 \%$ of that of Einstein's maximal energy in an astounding agreement with the highly accurate measurements of COBE, WMAP, Type $\mathrm{L}_{2}$ Supernova and Planck [1]-[10]. Furthermore, comparing the result with other theoretical derivations, for instance the exact transfinite one obtained from the multiplicative five dimensional value of a zero set quantum particle $\phi^{5}$ and additive five dimensional value of an empty set quantum wave $5 \phi \quad[24][27]$ namely

$$
\begin{aligned}
\mathrm{E}(\mathrm{O}) & =\left(\phi^{5} / 2\right) m c^{2}=m c^{2} /(22+\mathrm{k}) \\
\mathrm{E}(\mathrm{D}) & =\left(5 \phi^{2} / 2\right) \mathrm{mc}^{2}=\mathrm{mc}^{2}(21+\mathrm{k} / 22+\mathrm{k}) \\
& =1-\mathrm{E}(\mathrm{O}),
\end{aligned}
$$

we find that setting the transfinite irrational tail $\mathrm{k}=\phi^{3}\left(1-\phi^{3}\right)=0.18033989$ equal zero leads to the very same result obtained using the Betti numbers $b_{2}$ of the said $K 3$ Kähler manifold [2] [44]. From the above it was concluded sometime ago that $b_{2}$ measures the amount of "space" voids in the manifold [10] [24] [28] [50] [52]. Consequently since the classical Einstein spacetime manifold is a smooth voidless manifold for which $\mathrm{b}_{2}=1$ and K3-Kähler manifold is a highly non-smooth four dimensional structure with $b_{2}=22$, we see that the topological index $b_{2}$ is a quite accurate measure for the fractal ruggedness involved for any manifold [81]-[86]. Therefore the used ratio $\mathrm{E}$ (Einstein) $/ \mathrm{b}_{2}$ (Kähler) will account for the reduction of $\mathrm{E}=\mathrm{mc}^{2}$ to $\mathrm{E}(\mathrm{O})=\mathrm{mc}^{2} / 22$ and its dissection into two components as expressed in the by now reasonably well known equation

$$
\begin{aligned}
\mathrm{E} & =\mathrm{E}(\mathrm{O})+\mathrm{E}(\mathrm{D}) \\
& =\left(\mathrm{mc}^{2} / 22\right)+\mathrm{mc}^{2}(21 / 22) \\
& =\mathrm{mc}^{2} \\
& =\mathrm{E}(\text { Einstein })
\end{aligned}
$$

In the preceding equation $\mathrm{E}(\mathrm{D})$ makes no distinction between the dark matter and the pure dark energy components of $\mathrm{E}(\mathrm{D})$. By contrast in the present derivation we show how the topology of K3-Kähler and its various Betti numbers can discriminate between not only ordinary and dark energy but also between dark matter and pure dark energy. This remarkable result will be achieved here by utilizing the signature of K3Kähler $\tau$ and the entire set of all non-zero Betti numbers [24] [81]-[86]. In addition we will be able to reveal the subtle coupling between dark matter and pure dark energy [2]-[35].

\section{Analysis}

The present analysis rests almost entirely on the intuitively understandable fact that similar to the distinction between the zero set and the various empty set with increasing degree of emptiness used in E-Infinity theory [83]-[103] the various topological Betti numbers measure subtly different degrees of ruggedness caused by the "voids" in the 
manifold [96] [101] [116]. In the spirit of the above, the heuristic dissection of E (Einstein)

$$
\begin{aligned}
\mathrm{E}(\text { Einstein }) & =\left(\mathrm{mc}^{2} / 22\right)+\mathrm{mc}^{2}(21 / 22) \\
& =\mathrm{E}(\mathrm{O})+\mathrm{E}(\mathrm{D}) \\
& =\mathrm{mc}^{2}
\end{aligned}
$$

may be rewritten to become

$$
\begin{aligned}
\mathrm{E}(\text { Einstein }) & =\mathrm{E}(\mathrm{O})+\mathrm{E}(\mathrm{DM})+\mathrm{E}(\mathrm{PDE}) \\
& =\left(\mathrm{mc}^{2} / 22\right)+\mathrm{mc}^{2}(5 / 22)+\mathrm{mc}^{2}(16 / 22)
\end{aligned}
$$

In turn this may be interpreted in terms of the topological invariant of our K3Kähler, namely [81]-[91]

$$
\begin{aligned}
& \mathrm{b}_{0}=\mathrm{b}_{4}=1, \quad \mathrm{~b}_{1}=\mathrm{b}_{3}=0, \\
& \mathrm{~b}_{2}^{-}=19, \quad \mathrm{~b}_{2}^{+}=3, \\
& \mathrm{~b}_{2}=\mathrm{b}_{2}^{+}+\mathrm{b}_{2}^{-}=3+19=22 \text { and } \\
& \tau=\mathrm{b}_{2}^{+}-\mathrm{b}_{2}^{-}=3-19=-16
\end{aligned}
$$

to mean that

$$
\begin{aligned}
\mathrm{E}(\text { Einstein }) & =\left(\frac{1}{\mathrm{~b}_{2}}\right) \mathrm{mc}^{2}+\left(\frac{\mathrm{b}_{0}+\mathrm{b}_{3}^{+}+\mathrm{b}_{4}}{\mathrm{~b}_{2}}\right) \mathrm{mc}^{2}+\frac{|\tau|}{\mathrm{b}_{2}} \mathrm{mc}^{2} \\
& =\frac{\mathrm{mc}^{2}}{22}+\left(\frac{5}{22}\right) \mathrm{mc}^{2}+\left(\frac{|-16|}{22}\right) \mathrm{mc}^{2} \\
& =\mathrm{mc}^{2}\left(\frac{1+5+16}{22}\right) \\
& =\mathrm{mc}^{2}
\end{aligned}
$$

This is a new profound confirmation of our previous result and reinforces the confidence in the K-(or K3) Kähler gained from its use in superstring theory and E-Infinity theory alike [2]-[108]. In particular one should note that the negative sign of the signature $\tau=-16$ can be interpreted as a clear hint that pure dark energy works in the opposite direction to dark matter and ordinary energy [1]-[80]. It is also note worthy to observe that the above result agrees almost completely with that obtained from the geometry of Kerr black holes [8].

\section{The Coupling of Dark Matter to Pure Dark Energy}

There is a subtle point in the previous integer approximation of the triple partitions of E-Einstein. The point is that the ordinary energy part $\mathrm{E}(\mathrm{O})=\mathrm{mc}^{2} / 22$ and the total dark energy part $\mathrm{E}(\mathrm{D})=\mathrm{mc}^{2} / 22$ may be found directly from the exact transfinite value $\mathrm{E}(\mathrm{O})=\mathrm{mc}^{2} /(22+\mathrm{k})$ and $\mathrm{E}(\mathrm{D})=\mathrm{mc}^{2}(21+\mathrm{k} / 22+\mathrm{k})$ by setting $\mathrm{k}=0$ and revealing $\mathrm{E}(\mathrm{O})$ to be $1 / 22 \simeq 4.5 \%$ and $\mathrm{E}(\mathrm{D})$ to be $21 / 22 \simeq 95.5 \%$ of the total energy [2]-[10]. However doing the same for the triple dissection, we do not find $\mathrm{E}(\mathrm{DM})$ to be equal to 
$22 \%$ nor $\mathrm{E}(\mathrm{PDF})$ to be $\simeq 73.5 \%$ as should be because $5 / 22 \simeq 22.7 \%$ and

$16 / 22 \simeq 72.7 \%$ [1]-[15]. Thus while our "integer" solution is quite close to the exact value they are not exact nor can they be made exact by setting small irrational tails such as k equal zero similar to the analysis involving two components dissection [1]-[80].

The deeper reason for this mathematical "anomaly" is that the "mathematics" is trying to tell us something of physical value and meaning. This "something" is actually that dark matter and pure dark energy are subtly coupled as the following computation will reveal. To do that we introduce the irrational transfinite correction coupling constant $\Delta=\left(8+\mathrm{k}^{2}\right) / 100$.

Rewriting our previous triadic $\mathrm{E}$ using $\Delta$ we find:

$$
\mathrm{E}=\mathrm{mc}^{2}\left[\frac{1}{22+\mathrm{k}}+\frac{5-\Delta}{22+\mathrm{k}}+\frac{16+\mathrm{k}+\Delta}{22+\mathrm{k}}\right]
$$

The remarkable fact is that in the above formalism everything falls in place and we find our exact solution that was found long ago using elaborate and occasionally terse reasoning namely that [8] [24]

$$
\begin{aligned}
& \mathrm{E}(\mathrm{O})=\mathrm{mc}^{2} / 22+\mathrm{k} \simeq \mathrm{mc}^{2} / 22=4.5 \% \\
& \mathrm{E}(\mathrm{DM})=\mathrm{mc}^{2}\left(\frac{5-\Delta}{22+\mathrm{k}}\right)=(22+\mathrm{k}) \% \simeq 22 \% \\
& \mathrm{E}(\mathrm{PDE})=\mathrm{mc}^{2}\left(\frac{16+\mathrm{k}+\Delta}{22+\mathrm{k}}\right) \simeq 73.5 \%
\end{aligned}
$$

exactly as obtained in numerous previous publications [1]-[80] and in full agreement with actual cosmic measurements [1]-[80]. In view of the above one could understand the huge difficulties of detecting dark matter to the extent of doubting its very real existence [132]. The present Author is however of the opinion that there is sufficient observation and theoretical underpinning to convince us that dark energy and dark matter are real [24].

\section{Conclusion}

By design or providence, superstring theory struck a lucky accord with nature by hitting on the marvelous K3-Kähler manifold. However, the inherent inconsistency of using a classical continuum in the form of vibrating and rotating strings coupled to a fundamental discrete ten dimensional network spacetime might be the reason of the failure of string theory in utilizing this K3-Kähler to its utmost capacity. By contrast when introducing a fuzzy-fractal version of K3-Kähler, we are able to use it beyond the compactification procedure of superstring theory to model spacetime itself. Proceeding in this way, a theory was developed which is essentially an E-Infinity-like theory with a twist. In this theory, the fundamental invariants of K3-Kähler, namely the Betti numbers, the signature and the Euler invariants, play a pivotal role not only in deriving the actually measured cosmic ordinary and dark energy density i.e. $\mathrm{E}(\mathrm{O})$ and $\mathrm{E}(\mathrm{D})$ but also of discriminating between pure dark energy $\mathrm{E}(\mathrm{PDE})$ and dark matter $\mathrm{E}(\mathrm{DM})$ as well as 
revealing its coupled nature.

\section{References}

[1] El Naschie, M.S. (2013) Journal of Quantum Information Science, 3, 23-26. http://dx.doi.org/10.4236/jqis.2013.31006

[2] El Naschie, M.S. (2013) International Journal of Modern Nonlinear Theory \& Application, 2, 43-54. http://dx.doi.org/10.4236/ijmnta.2013.21005

[3] El Naschie, M.S. (2013) Journal of Modern Physics, 4, 354-356. http://dx.doi.org/10.4236/jmp.2013.43049

[4] El Naschie, M.S. (2014) Journal of Quantum Information Science, 4, 83-91.

[5] El Naschie, M.S. (2013) Open Journal of Microphysics, 3, Article ID: 35744. http://dx.doi.org/10.4236/ojm.2013.33012

[6] Lahanas, A.B., Mavromatos, N.E. and Nanopoulosd, D.V. (2003) International Journal of Modern Physics D, 12, 1529. http://dx.doi.org/10.1142/S0218271803004286

[7] El Naschie, M.S. and Helal, A. (2013) International Journal of Astronomy and Astrophysics, 3, 318-343. http://dx.doi.org/10.4236/ijaa.2013.33037

[8] El Naschie, M.S. (2015) Natural Science, 7, 210-225. http://dx.doi.org/10.4236/ns.2015.74024

[9] Marek-Crnjac, L., El Naschie, M.S. and He, J.-H. (2013) International Journal of Modern Nonlinear Theory and Application, 2, 78-88. http://dx.doi.org/10.4236/ijmnta.2013.21A010

[10] El Naschie, M.S. (2013) International Journal of Modern Nonlinear Theory and Application, 2, 107-121. http://dx.doi.org/10.4236/ijmnta.2013.22014

[11] Lahanas, A.B., Mavromatos, N.E. and Nanopoulosd, D.V. (2007) Physics Letters B, 649, 83-90. http://dx.doi.org/10.1016/j.physletb.2007.03.058

[12] El Naschie, M.S. (2014) American Journal of Astronomy \& Astrophysics, 2, 72-77. http://dx.doi.org/10.11648/j.ajaa.20140206.13

[13] El Naschie, M.S. (2013) International Journal of Astronomy and Astrophysics, 3, Article ID: 40590. http://dx.doi.org/10.4236/ijaa.2013.34056

[14] El Naschie, M.S. (2013) Journal of Modern Physics and Applications, 2, No. 1.

[15] El Naschie, M.S. (2014) Open Journal of Fluid Dynamics, 4, 15-17. http://dx.doi.org/10.4236/ojfd.2014.41002

[16] El Naschie, M.S. (2014) International Journal of Modern Nonlinear Theory and Application, 3, 1-5. http://dx.doi.org/10.4236/ijmnta.2014.31001

[17] El Naschie, M.S., Marek-Crnjac, L., Helal, M.A. and He, J.-H. (2014) Applied Mathematics, 5, 1780-1790. http://dx.doi.org/10.4236/am.2014.512171

[18] El Naschie, M.S. (2015) The Open Astronomy Journal, 8, 1-17. http://dx.doi.org/10.2174/1874381101508010001

[19] El Naschie, M.S. (2014) Journal of Modern Physics Applications, 6, 1-10.

[20] El Naschie, M.S. (2014) Journal of Quantum Information Science, 4, 284-291. http://dx.doi.org/10.4236/jqis.2014.44023

[21] El Naschie, M.S. (2014) Journal of Applied Mathematics and Physics, 2, 803-806. http://dx.doi.org/10.4236/jamp.2014.28088

[22] Helal, M., Marek-Crnjac, L. and He, J.-H. (2013) Open Journal of Microphysics, 3, 141-145. http://dx.doi.org/10.4236/ojm.2013.34020 
[23] El Naschie, M.S. (2014) International Journal of Astronomy and Astrophysics, 4, 80-90. http://dx.doi.org/10.4236/ijaa.2014.41009

[24] Marek-Crnjac, L. and He, J.-H. (2013) International Journal of Astronomy and Astrophysics, 3, 464-471. http://dx.doi.org/10.4236/ijaa.2013.34053

[25] El Naschie, M.S. (2014) Problems of Nonlinear Analysis in Engineering Systems, 20, 79-98.

[26] El Naschie, M.S. (2013) American Journal of Modern Physics, 2, 357-361 http://dx.doi.org/10.11648/j.ajmp.20130206.23

[27] El Naschie, M.S. (2013) Journal of Modern Physics, 4, 591-596. http://dx.doi.org/10.4236/jmp.2013.45084

[28] El Naschie, M.S. (2014) World Journal of Mechanics, 4, 153-156. http://dx.doi.org/10.4236/wjm.2014.46017

[29] El Naschie, M.S. (2015) Open Journal of Applied Sciences, 5, 313-324. http://dx.doi.org/10.4236/ojapps.2015.57032

[30] El Naschie, M.S. (2014) Journal of Modern Physics, 5, 743-750. http://dx.doi.org/10.4236/jmp.2014.59084

[31] El Naschie, M.S. (2013) Gravitation and Cosmology, 19, 151-155. http://dx.doi.org/10.1134/S0202289313030031

[32] El Naschie, M.S. (2014) Journal of Applied Mathematics and Physics, 2, 634-638. http://dx.doi.org/10.4236/jamp.2014.27069

[33] El Naschie, M.S. (2016) Quantum Matter, 5, 1-4. http://dx.doi.org/10.1166/qm.2016.1247

[34] Marek-Crnjac, L. and El Naschie, M.S. (2013) Applied Mathematics, 4, 22-29. http://dx.doi.org/10.4236/am.2013.411A2005

[35] El Naschie, M.S. (2014) World Journal of Condensed Matter Physics, 4, 74-77. http://dx.doi.org/10.4236/wjcmp.2014.42011

[36] El Naschie, M.S. (2015) Natural Science, 7, 287-298. http://dx.doi.org/10.4236/ns.2015.76032

[37] He, J.H. and Marek-Crnjac, L. (2013) International Journal of Modern Nonlinear Theory and Application, 2, 55-59. http://dx.doi.org/10.4236/ijmnta.2013.21006

[38] Sidharth, B.G. (2003) Chaos, Solitons \& Fractals, 18, 197-201. http://dx.doi.org/10.1016/S0960-0779(02)00632-X

[39] Sidharth, B. and Altaisky, M.V. (2012) Frontiers of Fundamental Physics 4. Springer, Berlin.

[40] El Naschie, M.S. (2015) World Journal of Condensed Matter Physics, 5, 249-260. http://dx.doi.org/10.4236/wjcmp.2015.54026

[41] El Naschie, M.S. (2015) International Journal of Astronomy \& Astrophysics, 5, 243-247. http://dx.doi.org/10.4236/ijaa.2015.54027

[42] El Naschie, M.S. (2015) Natural Science, 7, 483-487. http://dx.doi.org/10.4236/ns.2015.710049

[43] El Naschie, M.S. (2015) Journal of Modern Physics, 6, 1321-1333. http://dx.doi.org/10.4236/jmp.2015.69137

[44] He, J.H. and Marek-Crnjac, L. (2013) Fractal Spacetime and Noncommutative Geometry in Quantum \& High Energy Physics, 3, 130-137.

[45] El Naschie, M.S. (2014) International Journal of Astronomy and Astrophysics, 4, 332-339. http://dx.doi.org/10.4236/ijaa.2014.42027 
[46] El Naschie, M.S. (2013) Journal of Quantum Information Science, 3, 55-57. http://dx.doi.org/10.4236/jqis.2013.32011

[47] El Naschie, M.S. (2013) International Journal of Astronomy and Astrophysics, 3, 205-211. http://dx.doi.org/10.4236/ijaa.2013.33024

[48] El Naschie, M.S. (2015) Open Journal of Microphysics, 5, 11-15. http://dx.doi.org/10.4236/ojm.2015.52002

[49] El Naschie, M.S. (2015) World Journal of Nano Science and Engineering, 5, 57-67. http://dx.doi.org/10.4236/wjnse.2015.53008

[50] El Naschie, M.S. (2015) Advances in Pure Mathematics, 5, 560-570. http://dx.doi.org/10.4236/apm.2015.59052

[51] Marek-Crnjac, L. (2015) Natural Science, 7, 581-598. http://dx.doi.org/10.4236/ns.2015.713058

[52] El Naschie, M.S. (2015) Open Journal of Philosophy, 5, 123-130. http://dx.doi.org/10.4236/ojpp.2015.51014

[53] El Naschie, M.S. (2015) Open Journal of Philosophy, 5, 319-326. http://dx.doi.org/10.4236/ojpp.2015.56040

[54] El Naschie, M.S. (2013) Journal of Modern Physics, 4, 1417-1428. http://dx.doi.org/10.4236/jmp.2013.410170

[55] El Naschie, M.S. (2014) World Journal of Nuclear Science and Technology, 4, 216-221. http://dx.doi.org/10.4236/wjnst.2014.44027

[56] El Naschie, M.S. (2014) Journal of Electromagnetic Analysis and Applications, 6, 233-237. http://dx.doi.org/10.4236/jemaa.2014.69023

[57] Capozziello, S. (2002) International Journal of Modern Physics D, 11, 483-491. http://dx.doi.org/10.1142/S0218271802002025

[58] El Naschie, M.S. (2013) Journal of Modern Physics, 2, 18-23.

[59] Ellis, J.R., Mavromatos, N.E., Mitsou, V.A. and Nanopoulos, D.V. (2007) Astroparticle Physics, 27, 185-198. http://dx.doi.org/10.1016/j.astropartphys.2006.10.007

[60] El Naschie, M.S. (2013) Journal of Modern Physics, 4, 31-38. http://dx.doi.org/10.4236/jmp.2013.411A1005

[61] Iovane, G., Laserra, E. and Giordano, P. (2004) Chaos, Solitons \& Fractals, 22, 521-528. http://dx.doi.org/10.1016/j.chaos.2004.02.026

[62] Tang, W., Li, Y., Kong, H.Y. and El Naschie, M.S. (2014) Bubbfil Nanotechnology, 1, 3-12.

[63] Diamandis, G.A., Georgalas, B.C., Mavromatos, N.E. and Papantonopoulos, E. (2002) International Journal of Modern Physics A, 17, 4567-4589. http://dx.doi.org/10.1142/S0217751X02010893

[64] El Naschie, M.S. (2014) Advances in Pure Mathematics, 4, 641-648. http://dx.doi.org/10.4236/apm.2014.412073

[65] El Naschie, M.S. (2015) American Journal of Nano Research and Application, 3, 33-40.

[66] El Naschie, M.S. (2015) World Journal of Nano Science \& Engineering, 5, 26-33. http://dx.doi.org/10.4236/wjnse.2015.51004

[67] Marek-Crnjac, L. (2013) American Journal of Modern Physics, 2, 255-263. http://dx.doi.org/10.11648/j.ajmp.20130205.14

[68] Iovane, G. (2004) Chaos, Solitons \& Fractals, 20, 657-667. http://dx.doi.org/10.1016/j.chaos.2003.09.036 
[69] El Naschie, M.S. (2005) Chaos, Solitons \& Fractals, 25, 969-977.

http://dx.doi.org/10.1016/j.chaos.2005.02.028

[70] El Naschie, M.S. (2016) Journal of Quantum Information Science, 6, 1-9. http://dx.doi.org/10.4236/jqis.2016.61001

[71] Fred, Y.Y. (2009) Chaos, Solitons \& Fractals, 42, 89-93. http://dx.doi.org/10.1016/j.chaos.2008.10.030

[72] Ellis, J., Mavromatos, N.E. and Nanopoulos, D.V. (2005) Physics Letters B, 619, 17-25. http://dx.doi.org/10.1016/j.physletb.2005.05.047

[73] El Naschie, M.S. (2016) World Journal of Condensed Matter Physics, 6, 63-67. http://dx.doi.org/10.4236/wjcmp.2016.62009

[74] Iovane, G., Laserra, E. and Tortoriello, F.S. (2004) Chaos, Solitons \& Fractals, 20, 415-426. http://dx.doi.org/10.1016/j.chaos.2003.08.004

[75] El Naschie, M.S. (2015) American Journal of Nano Research \& Application, 3, 66-70.

[76] El Naschie, M.S. (2015) Journal of Modern Physics, 6, 348-395. http://dx.doi.org/10.4236/jmp.2015.64042

[77] Greljo, A., Julio, J., Kamenik, J.F., Smith, C. and Zupan, J. (2013) Journal of High Energy Physics, 2013, 190. http://dx.doi.org/10.1007/jhep11(2013)190

[78] Diamandis, G.A., Georgalas, B.C., Lahanas, A.B., Mavromatos, N.E. and Nanopoulos, D.V. (2006) Physics Letters B, 642, 179-186. http://dx.doi.org/10.1016/j.physletb.2006.09.035

[79] El Naschie, M.S. (2006) World Journal of Nano Science and Engineering, 5, 49-56. http://dx.doi.org/10.4236/wjnse.2015.52007

[80] Sidharth, B.G. (2001) Chaos, Solitons \& Fractals, 12, 1101-1109. http://dx.doi.org/10.1016/S0960-0779(00)00079-5

[81] El Naschie, M.S. (2005) International Journal of Nonlinear Sciences and Numerical Simulation, 6, 95-98. http://dx.doi.org/10.1515/ijnsns.2005.6.2.95

[82] Gibbons, G., Shellard, E. and Rankin, S. (2003) The Future of Theoretical Physics and Cosmology. Cambridge University Press, Cambridge.

[83] El Naschie, M.S. (2006) Chaos, Solitons \& Fractals, 30, 579-605. http://dx.doi.org/10.1016/j.chaos.2006.03.030

[84] El Naschie, M.S. (2006) Chaos, Solitons \& Fractals, 29, 876-881. http://dx.doi.org/10.1016/j.chaos.2005.12.027

[85] El Naschie, M.S. (2007) International Journal of Nonlinear Science \& Numerical Simulation, 8, 11-20. http://dx.doi.org/10.1515/IJNSNS.2007.8.1.11

[86] El Naschie, M.S. (2005) Chaos, Solitons \& Fractals, 26, 477-481. http://dx.doi.org/10.1016/j.chaos.2004.12.024

[87] El Naschie, M.S. (2006) Chaos, Solitons \& Fractals, 27, 9-13. http://dx.doi.org/10.1016/j.chaos.2005.05.010

[88] El Naschie, M.S. (2006) Chaos, Solitons \& Fractals, 27, 39-42. http://dx.doi.org/10.1016/j.chaos.2005.04.094

[89] El Naschie, M.S. (2006) Chaos, Solitons \& Fractals, 27, 843-849. http://dx.doi.org/10.1016/j.chaos.2005.06.002

[90] El Naschie, M.S. (2005) Chaos, Solitons \& Fractals, 26, 1-6. http://dx.doi.org/10.1016/j.chaos.2005.02.031

[91] El Naschie, M.S. (2006) Chaos, Solitons \& Fractals, 30, 636-641. http://dx.doi.org/10.1016/j.chaos.2006.04.044 
[92] El Naschie, M.S. (2005) Chaos, Solitons \& Fractals, 25, 509-514. http://dx.doi.org/10.1016/j.chaos.2005.02.016

[93] El Naschie, M.S. (2006) Chaos, Solitons \& Fractals, 29, 816-822. http://dx.doi.org/10.1016/j.chaos.2006.01.013

[94] El Naschie, M.S. (2007) Chaos, Solitons \& Fractals, 31, 537-547. http://dx.doi.org/10.1016/j.chaos.2006.07.001

[95] El Naschie, M.S. (2007) International Journal of Nonlinear Sciences and Numerical Simulation, 8, 445-450. http://dx.doi.org/10.1515/IJNSNS.2007.8.3.445

[96] El Naschie, M.S. (2005 Chaos, Solitons \& Fractals, 26, 665-670. http://dx.doi.org/10.1016/j.chaos.2005.01.018

[97] El Naschie, M.S. (2007) Chaos, Solitons \& Fractals, 32, 427-430. http://dx.doi.org/10.1016/j.chaos.2006.09.016

[98] El Naschie, M.S. (2006) Chaos, Solitons \& Fractals, 30, 1025-1033. http://dx.doi.org/10.1016/j.chaos.2006.05.088

[99] El Naschie, M.S. (2006) Chaos, Solitons \& Fractals, 29, 845-853. http://dx.doi.org/10.1016/j.chaos.2006.01.073

[100] El Naschie, M.S. (2005) International Journal of Nonlinear Sciences and Numerical Simulation, 6, 331-333. http://dx.doi.org/10.1515/IJNSNS.2005.6.3.331

[101] El Naschie, M.S. (2005) Chaos, Solitons \& Fractals, 26, 303-311. http://dx.doi.org/10.1016/j.chaos.2005.03.004

[102] El Naschie, M.S. (2005) Chaos, Solitons \& Fractals, 26, 291-294. http://dx.doi.org/10.1016/j.chaos.2005.03.003

[103] El Naschie, M.S. (2007) Chaos, Solitons \& Fractals, 32, 370-374. http://dx.doi.org/10.1016/j.chaos.2006.09.018

[104] El Naschie, M.S. (2006) Chaos, Solitons \& Fractals, 30, 525-531. http://dx.doi.org/10.1016/j.chaos.2005.04.123

[105] El Naschie, M.S. (2006) Chaos, Solitons \& Fractals, 29, 803-807. http://dx.doi.org/10.1016/j.chaos.2006.01.012

[106] El Naschie, M.S. (2005) Chaos, Solitons \& Fractals, 25, 521-524. http://dx.doi.org/10.1016/j.chaos.2005.01.022

[107] El Naschie, M.S. (2008) Chaos, Solitons \& Fractals, 35, 7-12. http://dx.doi.org/10.1016/j.chaos.2007.06.023

[108] El Naschie, M.S. (2008) Chaos, Solitons \& Fractals, 35, 67-70. http://dx.doi.org/10.1016/j.chaos.2007.05.013

[109] Krauss, L.M. (2001) Quintessence. Published by Vintage.

[110] El Naschie, M.S. (2015) International Journal of High Energy Physics, 2, 13-21. http://dx.doi.org/10.11648/j.ijhep.20150201.12

[111] Mills, R. (1994) Space, Time and Quantra. W. H. Freeman, New York.

[112] El Naschie, M.S. (2015) International Journal of Innovation in Science and Mathematics, 3, 254-265.

[113] El Naschie, M.S. (2016) Journal of Quantum Information Science, 6, 57-61. http://dx.doi.org/10.4236/jqis.2016.62007

[114] Kragh, H. (1996) Cosmology and Controversy. Princeton University Press, Princeton, NJ.

[115] Mumford, D., Series, C. and Wright, D. (2002) Indra’s Pearls. Cambridge University Press, Cambridge. 
[116] Rogers, B., Pennathur, S. and Adams, J. (2008) Nanotechnology. CRC Press, Boca Raton.

[117] El Naschie, M.S. (2015) Problems of Nonlinear Analysis in Engineering Systems, 2, 1-16.

[118] Hsu, J.-P. and Hsu, L. (2006) A Broad View of Relativity. World Scientific, Singapore.

[119] El Naschie, M.S. (2015) American Journal of Nano Research and Applications, 3, 1-5.

[120] El Naschie, M.S. (2016) Natural Science, 8, 152-159. http://dx.doi.org/10.4236/ns.2016.83018

[121] El Naschie, M.S. (2016) Journal of Modern Physics, 7, 729-736. http://dx.doi.org/10.4236/jmp.2016.78069

[122] El Naschie, M.S. (2016) International Journal of Astronomy and Astrophysics, 6, 135-144. http://dx.doi.org/10.4236/ijaa.2016.62011

[123] El Naschie, M.S. (2016) American Journal of Computational Mathematics, 6, 185-199. http://dx.doi.org/10.4236/ajcm.2016.63020

[124] El Naschie, M.S. (2015) American Journal of astronomy and Astrophysics, 3, 77-86. http://dx.doi.org/10.11648/j.ajaa.20150305.11

[125] Babchin, A.J. and El Naschie, M.S. (2015) World Journal of Condensed Matter Physics, 6, 1-6. http://dx.doi.org/10.4236/wjcmp.2016.61001

[126] El Naschie, M.S. (2016) Advances in Pure Mathematics, 6, 446-454. http://dx.doi.org/10.4236/apm.2016.66032

[127] Ho, M.E.N. and Giuseppe Vitiello, M.W. (2015) Global Journal of Science Frontier Research, 15, 61-80.

[128] El Naschie, M.S. (2016) International Journal of Astronomy and Astrophysics, 6, 56-81. http://dx.doi.org/10.4236/ijaa.2016.61005

[129] Auffray, J.P. and El Naschie, M.S. (2016) Journal of Modern Physics, 7, 156-161. http://dx.doi.org/10.4236/jmp.2016.71017

[130] El Naschie, M.S. (2016) Journal of Modern Physics, 7, 1420-1428. http://dx.doi.org/10.4236/jmp.2016.712129

[131] El Naschie, M.S. (2016) Journal of Applied Mathematics and Physics, 4, 979-987. http://dx.doi.org/10.4236/jamp.2016.46105

[132] Brownstein, J.R. and Moffat, J.W. (2007) Monthly Notices of the Royal Astronomical Society, 382, 29-47. http://dx.doi.org/10.1111/j.1365-2966.2007.12275.x 
Submit or recommend next manuscript to SCIRP and we will provide best service for you:

Accepting pre-submission inquiries through Email, Facebook, LinkedIn, Twitter, etc. A wide selection of journals (inclusive of 9 subjects, more than 200 journals)

Providing 24-hour high-quality service

User-friendly online submission system

Fair and swift peer-review system

Efficient typesetting and proofreading procedure

Display of the result of downloads and visits, as well as the number of cited articles

Maximum dissemination of your research work

Submit your manuscript at: http://papersubmission.scirp.org/

Or contact jmp@scirp.org 